НАУКОВИЙ ВІСНИК Mसतम

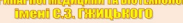
entific messenger of L Liv National Lniven
Veterinarv Medicine and Biotech hologeies rathen $<$ 11) IN MIN

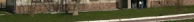
Tom ТМ 21 № 2019
Науковий вісник Аьвівського національного університету ветеринарної медицини та біотехнодогій імені С.3. Гжицького. Серія: Харчові технологіі

Scientific Messenger of Lviv National University of Veterinary Medicine and Biotechnologies.

Series: Food Technologies

UDC 664.662.016.8:339.13(477)

\title{
Assessment of the quality and competitiveness of bread made from a mixture of rye and wheat flour on the Ukrainian market
}

\author{
T.V. Bozhko, R.S. Donchevska, O.V. Babii \\ Kyiv National University of Trade and Economics, Kyiv, Ukraine
}

Article info

Received 08.09.2019

Received in revised form 09.10 .2019

Accepted 10.10.2019

Kyiv National University of Trade and Economics, Kyoto Str., 19, Kyiv-156, 02156, Ukraine. Tel.: +38-097-543-76-30 E-mail:tatyana_bozhko@ukr.net
Bozhko, T.V., Donchevska, R.S., \& Babii, O.V. (2019). Assessment of the quality and competitiveness of bread made from a mixture of rye and wheat flour on the ukrainian market. Scientific Messenger of Lviv National University of Veterinary Medicine and Biotechnologies. Series: Food Technologies, 21(92), 28-35. doi: 10.32718/nvlvet-f9206

In order to determine the competitiveness of bread made from a mixture of rye and wheat flour sold in the Ukrainian market, the Ukrainian bakery market was analyzed and a comprehensive study of the quality of samples of different brands was conducted. On the basis of the analysis, the general trends of development are formulated and the reasons for the decrease in the demand for bakery products are identified. Quality assessment was carried out according to a set of organoleptic and physicochemical indicators for compliance with the requirements of DSTU 4583:2006 "Rye bread and a bread from mixture of rye and wheat flour. General Specifications". Organoleptic quality of assessment was performed according to the developed 5-point scale. Acidity was determined by the filtrate titration method. Bread's porosity was determined by the Zavyalov method using the Zhuravlev device by weighing four cylindrical notches of bread. The calculation of the integral quality index was performed taking into account the missing and reference values, using a complex method. The evaluation of the competitiveness of bread made from a mixture of rye and wheat flour was carried out by calculating the relative competitiveness indicator by functional, aesthetic and economic indicators, taking into account the weight coefficients. According to the results of complex qualimetric evaluation, the highest level of quality is characterized by the sample 5 - bread of TM "Kyivkhlib" (0.765), which is on average 15.04\% higher than other prototypes. This is due, first of all, to the better organoleptic characteristics of this sample and a crumb moisture content of $48.47 \%$, which is within the requirements of DSTU unlike other samples whose humidity is higher. A study of the competitiveness of bread made from a mixture of rye and wheat flour showed that sample 5 (Bread Borodynskii of TM "Kyivkhlib") is more competitive than the studied analogues. The latter is due to high aesthetics (appearance, stock of crumbs, taste, smell) and functional (humidity, acidity, porosity) of crumbs. Sample 3 (Bread Borodynskii TM of "Tsar Khlib") is also a sufficiently high integral competitive index (0.956), close to 1. The decrease in performance is related to the high cost of selling this product. Sample 2 (Bread Borodynskii of $T M$ "RIGA Bread") due to the low aesthetic, functional performance of, as well as the high cost of realization, the value of its integral competitiveness indicator was the lowest (0.317).

Key words: market, quality, bread from rye and wheat flour, competitiveness.

\section{Якість та конкурентоспроможність хліба із суміші житнього і пшеничного борошна на ринку України}

\author{
Т.В. Божко, Р.С. Дончевська, О.В. Бабій
}

Київський національний торговельно-економічний університет, м. Київ, Украӥна

3 метою визначення конкурентоспроможності хліба із суміші житнього і пшеничного борошна, що реалізується на ринку Украӥни, було проаналізовано вітчизняний ринок хлібобулочних виробів та проведено комплексне дослідження якості зразків різних торгових марок. На основі проведеного аналізу сформульовано загальні тенденції розвитку та виявлено причини зниження попиту на хлібобулочну продукиію. Оиінку якості здійснювали за комплексом органолептичних та фізико-хімічних показників на відповідність вимогам ДСТУ 4583:2006 “Хліб із житнього та сумімі житнього і пшеничного борошна. Загальні технічні умови”. Органо- 
лептичну очінку якості здійснювали за розробленою 5-баловою шкалою Кислотність визначали методом титрування фільтрату. Пористість хліба визначали методом Зав ялова із використанням приладу Журавльова шляхом зважування чотирьох ичиліндричних виїмок хліба. Розрахунок інтегрального показника якості здійснювали з урахуванням бракувальних та еталонних значень, застосовуючи комплексний метод. Оцінку конкурентоспроможності хліба із суміші житнього та пшеничного борошна здійснювали шляхом розрахунку показника відносної конкурентоспроможності за функціональними, естетичними та економічними показниками з урахуванням коефічієнтів вагомості. За результатами комплексного кваліметричного оцінювання, найвищим рівнем якості характеризується зразок 5 - хліб ТМ “Київліб” (0,765), шзо в середньому на 15,04\% перевищує інші дослідні зразки. Це обумовлено насамперед кращими органолептичними показниками даного зразка і показником вологості м'якушки 48,47\%, щчо перебувають у межах вимог ДСТУ на відміну від інших зразків, вологість яких є вищою. Дослідження конкурентоспроможності хліба із суміші житнього і пшеничного борочна показало, щуо зразок 5 (Хліб Бородинський ТМ “Київліб”) є більш конкурентоспроможним порівняно із досліджуваними аналогами. Останнє зумовлено високими естетичними (зовнішній вигляд, стан м'якушки, смак, запах) та функиіональними (вологість, кислотність, пористість м'якуики) показниками. Для зразку 3 (хліб Бородинський ТМ “Цар Хліб”) відмічено достатньо високий інтегральний показник конкурентоспроможності (0,956). Зниження показника пов'язано з високою ціною реалізації даного продукту. Зважаючи на низькі естетичні, функціональні показники зразка 2 (хліба Бородинського ТМ “RIGA Хліб”), а також високу изіну реалізації, значення його інтегрального показника конкурентоспроможності виявилося найнижчим (0,317).

\section{Ключові слова: Ринок, якість, хліб із суміші житнього та пшеничного борошна, конкурентоспроможність.}

\section{Вступ}

Раціональне харчування та споживання хліба згідно 3 фізіологічними нормами забезпечує умови для нормального фізичного та розумового розвитку організму, підтримує високу працездатність, сприяє профілактиці захворювань і здійснює суттєвий вплив на можливість організму протистояти дії несприятливих факторів навколишнього середовища. Проте в останні роки під впливом світових тенденцій обсяг виробництва хлібобулочних виробів в Україні знижується. Ці обставини разом зі скороченням кількості населення, призводять до щорічного скорочення місткості ринку в межах $5-10 \%$.

Хімічний склад хліба залежить, в основному, від рецептури та сорту борошна, з якого він виготовлений. Основною складовою хліба $є$ вуглеводи, їхній вміст в житньому хлібі з оббивного борошна складає від 40\%, сухарях - 70\%. Найбільшу питому вагу із вуглеводів хліба становить крохмаль і продукти його гідролізу: моносахариди, дисахариди. Серед вуглеводів у хлібі містяться такі нерозчинні полісахариди, як целюлоза, геміцелюлоза, клітковина, пектини, пентозани. Вміст білкових речовин у хлібі становить від 6,5 до $11 \%$. Вони представлені білками, а також продуктами гідролізу білків - поліпептидами, пептидами, амідами, амінокислотами. Серед амінокислот представлені всі незамінні: валін, ізолейцин, лейцин, лізин, метіонін, треонін, триптофан, фенілаланін. Загальний вміст органічних кислот у різних виробах становить $0,3-1,3 \%$.

Хліб є цінним джерелом мінеральних речовин (1,2 до 2,5\%). 3 макроелементів у хлібі містяться $\mathrm{Na}, \mathrm{K}$, $\mathrm{Ca}, \mathrm{Mg}, \mathrm{P}, \mathrm{S}, \mathrm{Cl}$ та інші, а з мікроелементів - Fe, I, Co, $\mathrm{Mn}, \mathrm{Mo}, \mathrm{F}, \mathrm{Cr}, \mathrm{Zn}$ та інші. До складу хліба входить комплекс життєво необхідних вітамінів групи В тіамін $\left(\mathrm{B}_{1}\right)$, рибофлавін $\left(\mathrm{B}_{2}\right)$, нікотинова кислота $(\mathrm{PP})$ та інші. Хліб містить 0,6-1,2\% жирів. Вони представлені тригліцеридами, насиченими і ненасиченими жирними кислотами (Kazanskaja, 2004).

Таким чином, хліб, на відміну від інших хлібобулочних виробів, характеризується вищою біологічною цінністю за рахунок вмісту незамінних амінокислот, мінеральних речовин, вітамінів. Виробники розширюють асортимент хліба за рахунок використання нової, часто нетрадиційної сировини для підвищення його біологічної цінності. Проте все частіше у рецептурах використовують стабілізатори, ферментні добавки і синтетичні розпушувачі. Їх надмірне споживання зумовлює зниження імунітету організму людини, порушення функціонування центральної нервової системи, виникнення алергії тощо (Galli et al., 2007; Bogomolova et al., 2018).

Висока соціальна значущість хліба та потреба у стабільному й своєчасному забезпеченні населення якісною продукцією зумовлюють необхідність дослідження та оцінки якості й конкурентоспроможності хліба із суміші житнього і пшеничного борошна.

Мета $i$ завдання досліджень - оцінка якості та конкурентоспроможності хліба із суміші житнього та пшеничного борошна, що реалізується на ринку України. Для досягнення поставленої мети слід було виконати такі завдання:

- проаналізувати сучасний стан і тенденції розвитку ринку хліба в Україні;

- провести дослідження органолептичних та фізико-хімічних показників хліба із суміші житнього та пшеничного борошна;

- розрахувати комплексний показник якості та визначити конкурентоспроможність досліджуваних зразків хліба.

\section{Матеріал і методи досліджень}

Об'єктом дослідження є хліб із суміші житнього та пшеничного борошна, що реалізується на ринку України:

- зразок 1 - хліб "Бородинський” ТМ “Кулиничі" (виробник ТОВ “Хлібокомбінат “Кулиничі”, смт. Кулиничі), маса нетто 500 г;

- зразок 2 - хліб Бородинський TM "RIGA Хліб" (виробник ТОВ “Ризький хліб”, м. Чернігів), маса нетто 300 г;

- зразок 3 - хліб Бородинський ТМ “Цар Хліб” (виробник ТОВ "Перший Столичний Хлібозавод", Київська обл.), маса нетто 500 г;

- зразок 4 - хліб Кумовський TM "RIGA Хліб” (виробник ТОВ “Ризький хліб”, м. Чернігів), маса нетто 300 г; 
- зразок 5 - хліб Бородинський ТМ “Київхліб” (виробник ПАТ “Київхліб”, м. Київ) маса нетто 400 г.

Предмет дослідження - споживні властивості, якість і конкурентоспроможність хліба із суміші житнього та пшеничного борошна.

Оцінку якості здійснювали за комплексом органолептичних (зовнішній вигляд, стан м'якушки, смак, запах) та фізико-хімічних (вологість м'якушки, кислотність та пористість) показників згідно з ДСТУ 4583:2006 "Хліб із житнього та суміші житнього i пшеничного борошна. Загальні технічні умови" (DSTU 4583:2006, 2007).

При оцінці зовнішнього вигляду хліба визначали форму, стан поверхні та колір - шляхом візуального огляду дослідних зразків. Стан м'якушки визначали за допомогою тактильних відчуттів - надавлюванням, розрізанням, а також при розжовуванні; крім того, при цьому встановлювали пропеченість, наявність слідів непромісу, липкості. При визначенні смаку та запаху встановлювали його характерність та наявність сторонніх присмаків та запахів.

Вологість хліба визначали методом висушування наважки до постійної маси та обчисленні вологості згідно з ГОСТ 21094 “Хлеб и хлебобулочные изделия. Метод определения влажности” (GOST 21094-75, 1976).

Кислотність визначали методом титрування фільтрату, приготованого з наважки хліба $(m)$ гідроокисом натрію за наявності фенолфталеїну та подальшого розрахунку кислотності згідно з ГОСТ 5670-96 “Хлебобулочные изделия. Метод определения кислотности" (GOST 5670-96, 1996):

$$
X=\frac{V \cdot V_{1} \bullet a}{10 m \cdot V_{2}} \times K
$$

де $V \quad-\quad$ об'єм розчину молярної концентрації 0,1 моль/дм ${ }^{3}$ гідроокису натрію, використаного для титрування досліджуваного розчину, $\mathrm{cm}^{3}$;

$V_{l}$ - об'єм дистильованої води, взятої для вилучення кислот $з$ досліджуваної продукції, $\mathrm{cm}^{3}$;

$V_{2}$ - об'єм досліджуваного розчину взятого для титрування, $\mathrm{cm}^{3}$;

$a$ - коефіцієнт перерахунку на 100 г наважки;

$K-$ поправочний коефіцієнт при переведенні використовуваного розчину до розчину точної молярної концентрації 0,1 моль/дм ${ }^{3}$.

Пористість хліба визначали методом Зав'ялова із використанням приладу Журавльова шляхом зважування чотирьох циліндричних виїмок хліба об'ємом $(27 \pm 0,5) \mathrm{cm}^{3}$ кожна та проведенням подальших розрахунків згідно з ГОСТ 5669 "Хлебобулочные изделия. Метод определения пористости” (GOST 5669-96, 1996).

Розрахунок інтегрального показника якості здійснювали 3 урахуванням бракувальних та еталонних значень, застосовуючи комплексний метод, який $\epsilon$ доцільним, коли треба характеризувати рівень якості зразка одним узагальнюючим показником, що являє собою функцію від одиничних показників якості (Sydorenko, 2005).

Органолептичні показники дослідних зразків хліба оцінювали за розробленою нами 5-баловою шкалою 3 урахуванням коефіцієнта вагомості (табл. 1).

\section{Таблиця 1}

Шкала балової оцінки органолептичних показників дослідних зразків хліба із суміші житнього та пшеничного борошна

\begin{tabular}{|c|c|c|c|}
\hline $\begin{array}{c}\text { Показники } \\
\text { якості }\end{array}$ & Бали & Характеристика показників & $\begin{array}{c}\text { Коефіцієнт } \\
\text { вагомості }\end{array}$ \\
\hline \multirow{5}{*}{$\begin{array}{l}\text { 1. Зовнішній } \\
\text { вигляд }\end{array}$} & 5 & Відповідає формі, без бокових випливів, забруднень, без підгорілості & \multirow{5}{*}{0,2} \\
\hline & 4 & Відповідає формі, з плоским верхом, без бокових випливів, без підгорілості & \\
\hline & 3 & $\begin{array}{l}\text { Незначна невідповідність форми, з незначною деформацією, незначними боковими } \\
\text { випливами }\end{array}$ & \\
\hline & 2 & $\begin{array}{l}\text { Форма деформована, з незначними боковими випливами, з незначною підгорілістю } \\
\text { або з блідим забарвленням }\end{array}$ & \\
\hline & 1 & Форма деформована, з боковими випливами, з підгорілістю & \\
\hline \multirow{5}{*}{$\begin{array}{l}\text { 2. Стан } \\
\text { м'якушки }\end{array}$} & 5 & Пропечена, без непромісу, з незначною липкістю & \multirow{5}{*}{0,2} \\
\hline & 4 & Пропечена, з одним непромісом, з незначною липкістю & \\
\hline & 3 & Пропечена, з незначними слідами непромісу, з незначною липкістю або сухуватістю & \\
\hline & 2 & Пропечена, нерівномірна з незначною липкістю & \\
\hline & 1 & Не пропечена, значні сліди непромісу, сухувата та липка & \\
\hline \multirow{5}{*}{ 3. Смак } & 5 & Властивий, без сторонніх присмаків & \multirow{5}{*}{0,3} \\
\hline & 4 & Властивий, недостатньо виражений, без сторонніх присмаків & \\
\hline & 3 & Властивий, не виражений & \\
\hline & 2 & Властивий, злегка кислуватий, невиражений, з незначним стороннім присмаком & \\
\hline & 1 & Не властивий даному виду виробів, зі стороннім присмаком & \\
\hline \multirow{5}{*}{ 4. Запах } & 5 & Властивий, без стороннього запаху, з легким солодовим ароматом & \multirow{5}{*}{0,3} \\
\hline & 4 & Властивий, недостатньо виражений, без сторонніх запахів & \\
\hline & 3 & Властивий, не виражений, з незначним стороннім запахом & \\
\hline & 2 & Не характерний, з кислим смаком або іншими сторонніми ароматами & \\
\hline & 1 & Не властивий даному виду виробів, зі стороннім запахом & \\
\hline
\end{tabular}


3 метою об'єктивної оцінки якості хліба формалізували критерії, тобто подавали їх у вигляді цифрових даних. Для цього застосували метод кваліметричної оцінки, який дозволяє отримати показник у вигляді деякої цифрової величини. Показники якості кожного зі зразків переводили у безрозмірний вигляд, застосовуючи таку формулу (Sydorenko, 2005):

$$
P_{i}=\frac{p_{i}-p_{i}^{\sigma p}}{p_{i}^{e m}-p_{i}^{\sigma p}},
$$

де $P_{i} \quad-\quad$ i-й показник якості в безмірному вигляді (відносний показник);

$p_{i}-$ i-й показник $\mathrm{y}$ натуральному вигляді (абсолютний показник якості);

$p_{i}^{\sigma p}-$ бракувальне (найгірше допустиме) значення і-го показника - це, як правило, нормативне значення;

$p_{i}^{e m}-$ еталонне (найкраще можливе) значення iго показника.

Інтегральний показник якості розраховували за формулою (Sydorenko, 2005):

$$
Q=\sum_{i=1}^{n} a_{i} * X_{i},
$$

де $a_{i}-$ коефіцієнт вагомості і-го показника;

$P_{i}$ - значення відносного органолептичного i-го показника якості, бали;

$n$ - кількість органолептичних показників якості.

Оцінку конкурентоспроможності хліба із суміші житнього та пшеничного борошна здійснювали шляхом розрахунку показника відносної конкурентоспроможності за функціональними, естетичними та економічними показниками, з урахуванням коефіцієнтів вагомості за формулою 4:

$$
\mathrm{K}=\frac{\mathrm{P}_{\phi}+\mathrm{P}_{\text {ecm. }}}{\mathrm{g}_{\text {eк. }}} .
$$

де $P_{\phi} \quad-\quad$ збірний параметричний індекс за функціональними показниками;

$P_{\text {ecm }}$ - збірний параметричний індекс за естетичними показниками;

$g_{\text {eк }}$ - параметричний індекс економічних показників.

Розрахунок збірного параметричного індексу для функціональних показників (Sydorenko, 2005):

$$
\mathrm{P}_{\phi}=\sum \mathrm{a}_{i} \mathrm{~g}_{i},
$$

де $a_{i}-$ коефіцієнт вагомості;

$g_{i}$ - відносний показник якості, який розраховували за формулою (Sydorenko, 2005):

$$
\mathrm{g}_{i}=\frac{\mathrm{p}_{\text {досл. }}}{\mathrm{p}_{\text {конк }}}
$$

$$
\begin{array}{rlll}
\text { де } \mathrm{p}_{\text {досл }}- & \text { значення параметра досліджуваного } \\
& \text { товару; } & & \\
\mathrm{p}_{\text {конк }}- & \text { значення параметра конкуруючого } \\
& \text { товару. }
\end{array}
$$

Розрахунок збірного параметричного індексу для естетичних показників (Sydorenko, 2005):

$$
P_{\text {ecm }}=\sum \mathrm{a}_{\mathrm{i}} \cdot g_{i}
$$

Розрахунок параметричного індексу для економічних показників:

$$
\begin{aligned}
\mathrm{g}_{\text {ек }}= & \frac{\mathrm{C}_{\text {дссл. }}}{\mathrm{C}_{\text {конк. }}} \\
\text { де } C_{\text {досл }}- & \text { цінові характеристики досліджуваного } \\
& \text { товару; } \\
C_{\text {конк }}- & \text { цінові характеристики конкуруючого } \\
& \text { товару (Sydorenko, 2005). }
\end{aligned}
$$

Якщо $K<1$, то досліджуваний зразок хліба із суміші житнього та пшеничного борошна має нижчу конкурентоспроможність порівняно 3 конкуруючим зразком. Якщо $K>1$, то досліджуваний зразок має вищу конкурентоспроможність порівняно зі зразком конкуруючим.

\section{Результати та їх обговорення}

Аналіз ринку хлібобулочних виробів в Україні показує, що основна маса виробників все ще зосереджена на виробництві традиційних соціальних сортів хліба, частка яких становить $80 \%$ від загального обсягу. Преміальні і функціональні види становлять 5\% і 3\% відповідно. Виявити справжні параметри ринку заважає наявність значного тіньового сегмента. Поєднання низькорентабельного виробництва 3 конкурентними перевагами тіньових підприємств ускладнює діяльність офіційних учасників ринку і перешкоджає модернізації виробництва (Vasylchenko, 2016).

Протягом останніх тринадцяти років на ринку хліба простежуються дві тенденції. По-перше, відбувається концентрація виробництва і створення великих об'єднань (холдингів) у декількох регіонах. По-друге, з'явилася велика кількість дрібних виробників, що спеціалізуються на виробництві окремих видів хлібобулочних виробів. Кількість таких підприємств досягає кількох тисяч, а питома вага, за різними оцінками, становить від 30 до 60\%. У зв'язку з цим близько 80\% хлібобулочних виробів в Україні виготовляється великими промисловими виробниками, інші 20\% продукції - міні-пекарнями, пекарнями в супермаркетах та іншими дрібними виробниками. Варто зазначити, що сьогодні рівень неврахованого виробництва оцінюється в 60-65\% усього ринку хліба, що призводить до зниження його якості й безпечності.

На сучасному етапі серед промислових виробників хліба та хлібобулочних виробів основна частка припадає на вертикально-інтегровані компанії: концерн "Хлібпром" (м. Львів), який охоплює 15,6\% ринку хлібопродуктів; ПАТ “Київхліб” (м. Київ) - 13,5\%; група "Lauffer Group" (м. Донецьк) - 13,0; ТОВ "ХК "Хлібні інвестиції" (м. Київ) - 11,1; ТМ “Кулиничі" (м. Харків) - 9,4; ТМ “Формула смаку” (м. Кропивницький) - 8,8; ТМ “Хлібодар” (м. Запоріжжя) - займає $5,9 \%$ ринку. Ці компанії-виробники постачають на ринок країни понад 3/4 обсягів хлібопродукції промислового виробництва (Sychevskyi et al., 2018; Khliba vdostal..., 2019).

Більш платоспроможні споживачі, - це зазвичай мешканці мегаполісів, що формують попит на нетрадиційні види хліба відповідно до рекомендацій дієтологів - білковий, бездріжджовий, з різними добавками. За новими смаками випічки покупці йдуть у кафе, 
кондитерські, міні-пекарні, що мають гнучкий асортимент відповідно до переваг клієнтів.

Всі запити українців у сфері хлібобулочних виробів, в основному, задовольняються вітчизняними виробниками (рис. 1). Імпорт настільки незначний, що його частка майже не помітна в загальному обсязі ринку. Водночас експорт українського хліба збільшується, і головним покупцем тут є США (Khliba vdostal..., 2019).

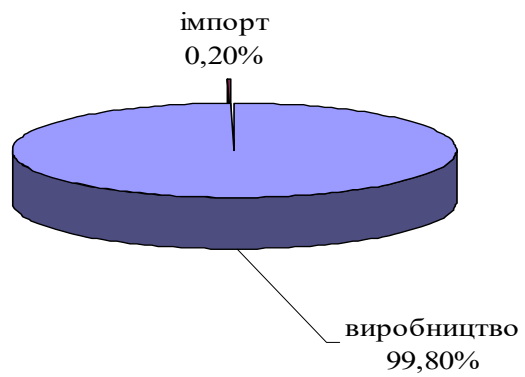

Рис. 1. Частки вітчизняної та імпортної продукції в структурі ринку хлібобулочних виробів в Україні, \% (Khliba vdostal..., 2019)

В Україні хліб та хлібобулочні вироби є доступними харчовими продуктами, які завжди $є$ на полицях магазинів (Sokolova et al., 2018). Серед асортименту хлібобулочної продукції переважає хліб пшеничний (рис. 2).

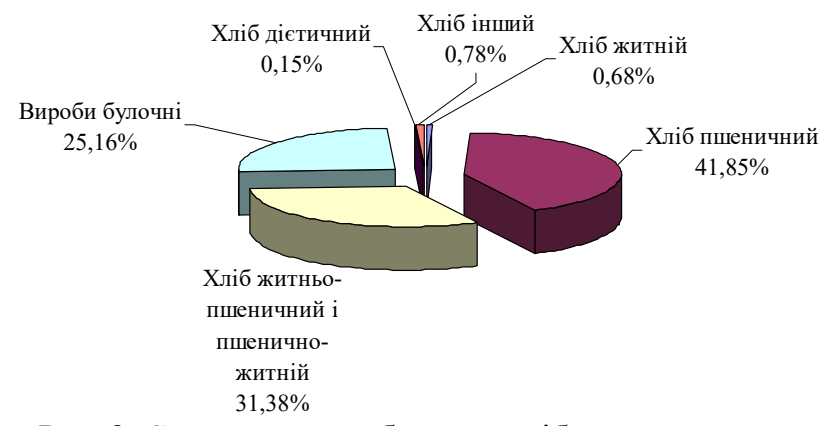

Рис. 2. Структура виробництва хліба за основними видами станом на 1 січня 2019 р.

Як видно з рис. 2, одним з найпопулярніших в Україні, незважаючи на негативну динаміку обсягів виробництва, є хліб із суміші житнього і пшеничного борошна. Саме тому оцінка якості та конкурентоспроможності хліба із суміші житнього та пшеничного борошна, на нашу думку, є актуальною та своєчасною.

Результати дослідження органолептичних та фізико-хімічних показників хліба із суміші житнього i пшеничного борошна, що реалізується на ринку України, наведено у табл. 2.

\section{Таблиця 2}

Результати дослідження органолептичних та фізико-хімічних показників хліба із суміші житнього і пшеничного борошна

\begin{tabular}{|c|c|c|c|c|c|}
\hline \multirow{2}{*}{$\begin{array}{c}\text { Назва } \\
\text { показника }\end{array}$} & \multicolumn{5}{|c|}{ Характеристика/значення показника } \\
\hline & Зразок 1 & Зразок 2 & Зразок 3 & Зразок 4 & Зразок 5 \\
\hline $\begin{array}{l}\text { Зовнішній } \\
\text { вигляд: } \\
\text { - форма }\end{array}$ & $\begin{array}{l}\text { Прямокутної форми, } \\
\text { без бокових випливів }\end{array}$ & $\begin{array}{c}\text { Прямокутної форми } \\
\text { зі злегка заокругле- } \\
\text { ним верхом, без } \\
\text { бокових випливів }\end{array}$ & $\begin{array}{c}\text { Прямокутної фор- } \\
\text { ми, без бокових } \\
\text { випливів }\end{array}$ & $\begin{array}{c}\text { Прямокутної фор- } \\
\text { ми з плоским вер- } \\
\text { хом, без бокових } \\
\text { випливів }\end{array}$ & $\begin{array}{c}\text { Прямокутної } \\
\text { форми з плоским } \\
\text { верхом, без } \\
\text { бокових випливів }\end{array}$ \\
\hline - поверхня & $\begin{array}{c}\text { Поверхня чиста, } \\
\text { гладенька, матова, } \\
\text { посипана коріандром }\end{array}$ & $\begin{array}{c}\text { Поверхня чиста, } \\
\text { гладенька, } 3 \\
\text { блиском } \\
\end{array}$ & $\begin{array}{l}\text { Поверхня чиста, } \\
\text { гладенька, матова }\end{array}$ & $\begin{array}{c}\text { Поверхня чиста, } \\
\text { гладенька, } 3 \\
\text { блиском } \\
\end{array}$ & $\begin{array}{l}\text { Поверхня чиста, } \\
\text { гладенька, матова }\end{array}$ \\
\hline - колір & $\begin{array}{l}\text { Темно-коричневий, } \\
\text { без підгорілості }\end{array}$ & $\begin{array}{c}\text { Темно-коричневий, } \\
\text { без підгорілості }\end{array}$ & $\begin{array}{c}\text { Коричневий, без } \\
\text { підгорілості }\end{array}$ & $\begin{array}{c}\text { Коричневий, без } \\
\text { підгорілості }\end{array}$ & $\begin{array}{c}\text { Темно-коричневий, } \\
\text { без підгорілості }\end{array}$ \\
\hline $\begin{array}{l}\text { Стан } \\
\text { м'якушки }\end{array}$ & $\begin{array}{c}\text { Пропечена, без слідів } \\
\text { непромісу, з незнач- } \\
\text { ною липкістю } \\
\end{array}$ & $\begin{array}{l}\text { Пропечена, однорі- } \\
\text { дна, злегка сухувата }\end{array}$ & $\begin{array}{c}\text { Пропечена, без } \\
\text { непромісу, пориста }\end{array}$ & $\begin{array}{c}\text { Пропечена, без } \\
\text { непромісу, пориста }\end{array}$ & $\begin{array}{c}\text { Пропечена, без } \\
\text { слідів непромісу, } 3 \\
\text { незначною липкістю } \\
\end{array}$ \\
\hline Смак & $\begin{array}{c}\text { Властивий даному } \\
\text { виду виробів, } 3 \\
\text { легким присмаком } \\
\text { прянощів } \\
\end{array}$ & $\begin{array}{c}\text { Властивий, злегка } \\
\text { солодкуватий та } \\
\text { кислуватий }\end{array}$ & $\begin{array}{c}\text { Властивий, без } \\
\text { сторонніх присмаків }\end{array}$ & $\begin{array}{c}\text { Властивий, без } \\
\text { сторонніх присмаків }\end{array}$ & $\begin{array}{c}\text { Властивий, легкий } \\
\text { присмак прянощів } \\
\text { і карамелі }\end{array}$ \\
\hline Запах & $\begin{array}{c}\text { Властивий даному } \\
\text { виду виробів, без } \\
\text { стороннього запаху } \\
\end{array}$ & $\begin{array}{c}\text { Властивий, з легким } \\
\text { ароматом солоду }\end{array}$ & $\begin{array}{c}\text { Властивий, без } \\
\text { сторонніх } \\
\text { запахів } \\
\end{array}$ & $\begin{array}{c}\text { Властивий, без } \\
\text { стороннього запаху }\end{array}$ & $\begin{array}{l}\text { Властивий, легкий } \\
\text { солодовий аромат }\end{array}$ \\
\hline $\begin{array}{l}\text { Вологість } \\
\text { м'якушки, \% }\end{array}$ & 38,24 & 39,04 & 40,03 & 40,00 & 48,47 \\
\hline $\begin{array}{l}\text { Кислотність } \\
\text { м'якушки, } \\
\text { град }\end{array}$ & 7,0 & 7,6 & 3,8 & 3,6 & 7,8 \\
\hline $\begin{array}{l}\text { Пористість } \\
\text { м'якушки, \% }\end{array}$ & 44,71 & 45,69 & 70,18 & 53,76 & 49,85 \\
\hline
\end{tabular}

За результатами органолептичної оцінки, всі досліджувані зразки хліба відповідали вимогам ДСТУ 4583:2006 (DSTU 4583:2006, 2007). Форма всіх зразків була прямокутною, правильною, без бокових випливів. Поверхня хліба Бородинського ТМ "Кулиничі" була покрита коріандром. Зразки хліба Бородинський 
TM "RIGA Хліб” і хліба Кумовський TM "RIGA Хліб” мали поверхню чисту, гладеньку, з блиском. Смак та запах всіх досліджуваних зразків були властивими для хліба з суміші житнього і пшеничного борошна, без сторонніх присмаків та запахів. Проте найкращими органолептичними властивостями характеризувався зразок 5 - хліб Бородинський ТМ “Київхліб” за рахунок властивого приємного смаку, з легким та гармонійним присмаком прянощів і карамелі, а також приємного запаху, з легким солодовим ароматом.

Варто зазначити, що вологість всіх зразків не перевищувала встановленої норми, хоча у зразку 1 (Хліб Бородинський ТМ “Кулиничі”) та зразку 2 (Хліб Бородинський TM "RIGA Хліб”) було встановлено іiі менший вміст порівняно 3 іншими зразками. Це й зумовило, на нашу думку, формування незначної сухуватості м'якушки даних зразків.

Кислотність м'якушки зразка 1 (Хліба Бородинського ТМ “Кулиничі”), зразка 2 (Хліба Бородинського TM “RIGA Хліб”) та зразка 5 - (Хліба Бородинського TM "Київхліб") - була в межах встановлених норм 7,0-7,8 ำ, тимчасом як для зразка 3 (Хліба Бородинського ТМ “Цар Хліб”) і зразка 4 (Хліба Кумовський TM "RIGA Хліб”) була занижена кислотність і становила 3,8 і 3,6 ${ }^{\circ} \mathrm{T}$ відповідно. Це зумовлено, на нашу думку, низькою якістю закваски або тривалим бродінням. Нижчою, у порівнянні з встановленими вимогами, виявлено пористість зразка 1 - хліба Бородинського 3 коріандром $(44,71 \%)$ та зразка 2 - хліба Бородинського TM "RIGA Хліб” (45,69\%). Це свідчить про нетривале замішування тіста, внаслідок чого процеси газоутворення при випіканні відбувалися недостатньо інтенсивно. Пористість зразка 1 - хліба Бородинського з коріандром ТМ “Кулиничі”, зразка 2 (хліба Бородинського TM "RIGA Хліб”), зразка 4 - Кумовський TM "RIGA Хліб” і зразка 5 - TM “Київхліб”, відповідала вимогам ДСТУ 4583:2006 і перебували в межах 44,71-53,76\%, тимчасом як пористість зразка 3 (ТМ “Цар Хліб”) порівняно з іншими зразками вияв- лено значно вищою, що свідчить про тривале бродіння тіста.

Отже, проаналізувавши органолептичні та фізикохімічні показники якості досліджуваних зразків хліба iз суміші житнього i пшеничного борошна, можна узагальнити, що лише зразок 5 (Хліб Бородинський ТМ “Київхліб”) повністю відповідав встановленим вимогам. Зразок 1 (хліб Бородинський ТМ “Кулиничі") та зразок 2 (хліб Бородинський TM “RIGA Хліб”) не відповідали вимогам ДСТУ 4583:2006 за фізикохімічними показниками, за рахунок низької пористості м'якушки, а зразок 3 (хліб Бородинський ТМ “Цар Хліб”) і зразок 4 (Хліб Кумовський TM “RIGA Хліб”) - за рахунок низької кислотності.

Наступним етапом експериментальної роботи була оцінка конкурентоспроможності хліба із суміші житнього і пшеничного борошна із використанням комплексного методу, який враховує функціональні, естетичні, економічні характеристики продукції. Він передбачає комплексну оцінку якості, в основі якої покладено такі принципи кваліметрії: формування еталонної множини показників, визначення коефіцієнтів вагомості, еталонних і бракувальних значень показників.

Перевагами кваліметричної оцінки є використання комплексного показника якості, який об'єднує значну кількість одиничних показників, забезпечуючи тим самим найбільш повну характеристику якості досліджуваної продукції. Крім того, даний метод сприяє об'єктивності та оперативності оцінки продукції за рахунок формалізації критеріїв якості, тобто представлення показників у вигляді масиву цифрових даних (Sydorenko, 2005).

Оцінку якості дослідних зразків хліба із суміші житнього і пшеничного борошна здійснювали за комплексом органолептичних (зовнішній вигляд, стан м'якушки, смак і запах) та фізико-хімічних показників (вологість, кислотність і пористість м'якушки). Обрані показники, на нашу думку, найповніше відображають якість досліджуваних зразків хліба. Комплексну оцінку якості наведено в табл. 3.

\section{Таблиця 3}

Комплексний показник якості досліджуваних зразків хліба із суміші житнього і пшеничного борошна

\begin{tabular}{|c|c|c|c|c|c|c|c|c|c|c|c|c|c|}
\hline \multirow[b]{2}{*}{ Показники } & \multirow{2}{*}{ 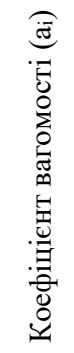 } & \multicolumn{2}{|c|}{$\begin{array}{c}\text { Порівнювані } \\
\text { значення } \\
\text { показника }\end{array}$} & \multicolumn{2}{|c|}{ Зразок 1} & \multicolumn{2}{|c|}{ Зразок 2} & \multicolumn{2}{|c|}{ Зразок 3} & \multicolumn{2}{|c|}{ Зразок 4} & \multicolumn{2}{|c|}{ Зразок 5} \\
\hline & & 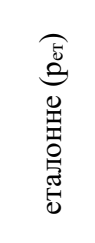 & 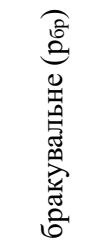 & 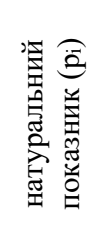 & 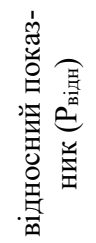 & $\mathrm{p}_{\mathrm{i}}$ & $\mathrm{P}_{\text {відн }}$ & $\mathrm{p}_{\mathrm{i}}$ & $\mathrm{P}_{\text {відн }}$ & $\mathrm{p}_{\mathrm{i}}$ & $\mathrm{P}_{\text {відн }}$ & $\mathrm{p}_{\mathrm{i}}$ & $\mathrm{P}_{\text {відн }}$ \\
\hline Зовнішній вигляд & 0,15 & 5 & 2 & 4,5 & 0,83 & 5 & 1,00 & 4,5 & 0,83 & 5 & 1,00 & 4,5 & 0,83 \\
\hline Стан м’якушки & 0,1 & 5 & 2 & 3,5 & 0,50 & 4 & 0,67 & 4,5 & 0,83 & 5 & 1,00 & 4 & 0,67 \\
\hline Смак & 0,2 & 5 & 2 & 4,5 & 0,83 & 4 & 0,67 & 4,5 & 0,83 & 4,5 & 0,83 & 5 & 1,00 \\
\hline Запах & 0,2 & 5 & 2 & 4,5 & 0,83 & 4,5 & 0,83 & 4,5 & 0,83 & 4,5 & 0,83 & 5 & 1,00 \\
\hline Вологість м’якушки & 0,15 & 53 & 41 & 38,24 & 0 & 39,04 & 0 & 40,03 & 0 & 40 & 0 & 48,47 & 0,62 \\
\hline Кислотність м'якушки & 0,1 & 5 & 12 & 7 & 0,71 & 7,6 & 0,63 & 3,8 & 1,17 & 3,6 & 1,20 & 7,8 & 0,60 \\
\hline Пористість м’якушки & 0,1 & 70,18 & 44,71 & 44,71 & 0,00 & 45,69 & 0,04 & 70,18 & 1,00 & 53,76 & 0,36 & 49,85 & 0,20 \\
\hline $\begin{array}{l}\text { Комплексний показник } \\
\text { якості }\end{array}$ & 1 & & & & 0,580 & & 0,583 & & 0,759 & & 0,739 & & 0,765 \\
\hline
\end{tabular}


За результатами комплексного кваліметричного оцінювання, найвищим рівнем якості характеризується зразок 5 - хліб ТМ “Київхліб” (0,765), що в середньому на 15,04\% перевищує інші дослідні зразки. Це обумовлено, насамперед кращими органолептичними показниками даного зразка і показником вологості м'якушки 48,47\%, що перебувають у межах вимог ДСТУ 4583:2006, на відміну від інших зразків, вологість яких є вищою.

Достатньо високий рівень якості виявлено у дослідних зразках 3 - хліб Бородинський ТМ "Цар Хліб" $(0,759)$ і 4 - Хліб Кумовський TM "RIGA Хліб” $(0,739)$ - за рахунок властивого смаку й запаху, низької кислотності.

Найнижче значення інтегрального показника якості характерне для зразків 1 - хліба Бородинського ТМ "Кулиничі” (0,580) і 2 - хліба Бородинського ТМ
“RIGA Хліб” (0,583), що на 24\% менше порівняно зі зразком 5 - хлібом ТМ “Київхліб”. Це пояснюється насамперед незначною липкістю або сухуватістю м'якушки, а також низькою вологістю та пористістю м'якушки, що не відповідає вимогам ДСТУ 4583:2006.

Оцінку конкурентоспроможності хліба із суміші житнього і пшеничного борошна здійснювали шляхом розрахунку інтегрального показника конкурентоспроможності за функціональними, естетичними та економічними показниками з урахуванням коефіцієнта вагомості. Товаром-конкурентом було визначено зразок 5 - хліб Бородинський ТМ “Київхліб” оскільки він характеризується найвищим рівнем якості порівняно з іншими зразками. Результати оцінки конкурентоспроможності наведено в табл. 4.

\section{Таблиця 4}

Оцінка конкурентоспроможності дослідних зразків хліба із суміші житнього і пшеничного борошна

\begin{tabular}{|c|c|c|c|c|c|c|c|c|c|c|}
\hline \multirow{2}{*}{$\begin{array}{c}\text { Показники конкуренто- } \\
\text { спроможності }\end{array}$} & \multirow{2}{*}{$\begin{array}{c}\begin{array}{c}\text { Коефіцієнт } \\
\text { вагомості }\end{array} \\
a_{i}\end{array}$} & \multirow{2}{*}{$\frac{\text { Зразок } 5}{\mathrm{P}_{\text {конк }}}$} & \multicolumn{2}{|c|}{ Зразок 1} & \multicolumn{2}{|c|}{ Зразок 2} & \multicolumn{2}{|c|}{ Зразок 3} & \multicolumn{2}{|c|}{ Зразок 4} \\
\hline & & & $\mathrm{P}_{\text {досл }}$ & $\mathrm{g}_{\mathrm{i}}$ & $\mathrm{P}_{\text {досл }}$ & $\mathrm{g}_{\mathrm{i}}$ & $\mathrm{P}_{\text {досл }}$ & $\mathrm{g}_{\mathrm{i}}$ & $\mathrm{P}_{\text {досл }}$ & $g_{i}$ \\
\hline \multicolumn{11}{|c|}{ Естетичні } \\
\hline Зовнішній вигляд & 0,15 & 0,83 & 0,83 & 1,00 & 1 & 1,20 & 0,83 & 1,00 & 1 & 1,20 \\
\hline Стан м'якушки & 0,1 & 0,67 & 0,5 & 0,75 & 0,67 & 1,00 & 0,83 & 1,24 & 1 & 1,49 \\
\hline Смак & 0,2 & 1 & 0,83 & 0,83 & 0,67 & 0,67 & 0,83 & 0,83 & 0,83 & 0,83 \\
\hline Запах & 0,2 & 1 & 0,83 & 0,83 & 0,83 & 0,83 & 0,83 & 0,83 & 0,83 & 0,83 \\
\hline $\begin{array}{l}\text { Збірний параметричний } \\
\text { індекс }\end{array}$ & & & & 0,56 & & 0,58 & & 0,61 & & 0,66 \\
\hline \multicolumn{11}{|c|}{ Функціональні: } \\
\hline Вологість м'якушки & 0,15 & 0,62 & 0 & 0 & 0 & 0 & 0 & 0 & 0 & 0 \\
\hline Кислотність м'якушки & 0,1 & 0,6 & 0,71 & 1,18 & 0,63 & 1,05 & 1,17 & 1,95 & 1,2 & 2,00 \\
\hline Пористість м'якушки & 0,1 & 0,2 & 0 & 0 & 0,04 & 0,20 & 1 & 5,00 & 0,36 & 1,80 \\
\hline $\begin{array}{l}\text { Збірний параметричний } \\
\text { індекс }\end{array}$ & & & & 0,12 & & 0,13 & & 0,70 & & 0,38 \\
\hline \multicolumn{11}{|c|}{ Економічні: } \\
\hline Роздрібна ціна, грн./100 г & $\mathrm{x}$ & 3,55 & 6,60 & 1,86 & 7,96 & 2,24 & 5,10 & 1,37 & 6,65 & 1,87 \\
\hline $\begin{array}{l}\text { Інтегральний показник } \\
\text { конкуренто-спроможності }\end{array}$ & 1 & $\mathrm{x}$ & & & & & & & 0,5 & \\
\hline
\end{tabular}

Згідно з отриманими результатами, всі досліджувані зразки поступаються конкурентоспроможністю конкуруючому, що обумовлено як органолептичними та фізико-хімічними показниками, так і вартістю 100 г продукції.

Таким чином, протягом останніх років на ринку хлібобулочних виробів простежується тенденція до зниження обсягу виробництва хліба традиційного асортименту за рахунок зміни рецептур та використання нових видів сировини підвищеної біологічної цінності. Крім того, змінився розподіл частки ринку серед виробників: близько $80 \%$ хлібобулочних виробів в Україні виготовляється великими промисловими виробниками, інші 20\% продукції - міні-пекарнями, пекарнями в супермаркетах та іншими дрібними виробниками. Однак зазначені дані можуть відрізнятись від фактичних, оскільки наразі рівень неврахованого виробництва оцінюється в 60-65\% обсягу ринку хліба, що призводить до зниження його якості й безпечності, а тому потребує подальших досліджень.
За результатами оцінки якості дослідних зразків хліба Бородинського, що реалізується на ринку України встановлено, що лише зразок 5 ТМ "Київхліб" відповідає вимогам ДСТУ 4583:2006 за усіма досліджуваними показниками та характеризується приємним смаком $з$ легким, гармонійним присмаком прянощів і карамелі та солодовим ароматом.

Таким чином, за результатами комплексної оцінки якості найвищий показник якості визначено для зразка 5 (хліб Бородинський ТМ “Київхліб”) - 0,765, найнижчий - для зразка 1 (хліб Бородинський 3 коріандром ТМ “Кулиничі”) - 0,580.

Дослідження конкурентоспроможності хліба із суміші житнього і пшеничного борошна показало, що зразок 5 (Хліб Бородинський ТМ “Київхліб”) є більш конкурентоспроможним порівняно із досліджуваними аналогами. Останнє зумовлено високими естетичними (зовнішній вигляд, стан м'якушки, смак, запах) та функціональними (вологість, кислотність, пористість м'якушки) показниками. У зразку 3 (хліб Бородинсь- 
кий ТМ “Цар Хліб”) виявлено достатньо високий інтегральний показник конкурентоспроможності $(0,956)$, що наближений до 1. Зниження показника зумовлено високою ціною реалізації даного продукту. Зважаючи на низькі естетичні, функціональні показники зразка 2 (хліба Бородинського TM "RIGA Хліб”), а також високу ціну реалізації, значення його інтегрального показника конкурентоспроможності виявилося найнижчим $(0,317)$.

\section{Висновки}

Таким чином, за результатами експериментальних досліджень встановлено, що основними факторами, які впливають на конкурентоспроможність хліба із суміші житнього і пшеничного борошна на вітчизняному ринку, є співвідношення ціна-якість, тому їхню конкурентоспроможність варто вивчати безперервно, цілеспрямовано i комплексно, орієнтуючись на задоволення потреб споживачів.

\section{References}

Bogomolova, S., Loch, A., Lockshin, L., Buckley, J. (2018). Consumer factors associated with purchasing local versus global value chain foods. Renewable Agriculture and Food Systems, 33(1), 33-46. doi: 10.1017/S1742170516000375.

DSTU 4583:2006 (2007). Khlib iz zhytnoho ta sumishi zhytnoho i pshenychnoho boroshna. Tekhnichni umovy. [Vved. 01.01.2007]. K.: Derzhspozhyvstandart Ukrainy (in Ukrainian).

Galli, F., Venturib, F., Bartolinic, F., Gavad, O., Zinnaie, A., Chiara, S. et al. (2017). Shaping food systems towards improved nutrition: a case study on Tuscan Bread Protected Designation of Origin. International Food and Agribusiness Management Review, 20(4), 533-552. doi: 10.22434/IFAMR2015.0174.
GOST 21094-75 (1976). Hleb i hlebobulochnye izdelija. Metod opredelenija vlazhnosti. [Vved. 01.06.1976]. M.: Gosstandart SSSR (in Russian).

GOST 5669-96 (1996). Hlebobulochnye izdelija. Metod opredelenija poristosti. [Vved. 01.08.1996]. Minsk: Mezhgosudarstvennyj sovet po standartizacii, metrologi i sertifikacii (in Russian).

GOST 5670-96 (1996). Hlebobulochnye izdelija. Metody opredelenija kislotnosti. [Vved. 01.08.1996]. Minsk: Mezhgosudarstvennyj sovet po standartizacii, metrologi i sertifikacii (in Russian).

Kazanskaja, L.N. (2004). Chto est' hleb? monografija. S.Peterb. fil. Gos. nauch.-issled. in-ta hlebopekar. promsti. Sankt-Peterburg: Beresta (in Russian).

Khliba vdostal, ale tsiny kusaiutsia: analiz rynku khlibobulochnykh vyrobiv v Ukraini (2019). [Elektronnyi resurs]. Rezhym dostupu: https://proconsulting.ua/ua/pressroom/hleba-vdovol-no-cenykusayutsya-analiz-rynka-hlebobulochnyh-izdelij-vukraine (in Ukrainian).

Sokolova, N., Kotuzaky, O.M., \& Pozhytkova, L.H. (2018). Analiz problem khlibopekarskoi haluzi, stan rynku ta aktualni shliakhy rozshyrennia asortymentu. Zernovi produkty i kombikormy, 18(1.3), 20-23. doi: 10.15673/gpmf.v18i3.1074 (in Ukrainian).

Sychevskyi, M.P., Vasylchenko, O.M., \& Kovalenko, O.V. (2018). Khlibopekarska haluz Ukrainy: tendentsii ta problemy yii rozvytku. Ekonomika APK, 5, 14-23. http://nbuv.gov.ua/UJRN/E_apk_2018_5_4 (in Ukrainian).

Sydorenko, O.V. (2005). Metodolohichni ta prykladni aspekty otsiniuvannia yakosti ta konkurentospromozhnosti tovariv. Standartyzatsiia. Sertyfikatsiia. Yakist, 1, 63-67 (in Ukrainian).

Vasylchenko, O.M. (2016). Ukrkhlibprom u tsyfrakh, zdobutkakh, problemakh i rozroblenykh retsepturakh. Khranenye y pererabotka zerna, 4, 4-7 (in Ukrainian). 